\title{
HISTORY OF LEAD AND ZINC MINING IN IOWA.
}

BY PROF. ARTHUR G. LEONARD.

From advance sheets of Vol, VI of the Iowa Geological Reports.

It is now nearly two bundred years since the white man discovered lead in the Upper Mississippi region. In 1700 the French explorer Le Sueur made an expedition up the great river from New Orleans in search of ores. Heascended as far as the Saint Peters River, now the Minuesota, and, it is generally supposed, observed lead at several points along the "Father of Waters." It is interesting to note that as long ago as 1752 the lead region of the Upper Mississippi was located on a map published during that year by Philippe Banche.* The mines are also mentioned briefly in an article by M. Guettard in the same volume, pp. 189-220, where they are described as being very rich.

In 1788 the first mining was done within the territory of what is now the State of Iowa. In that year Julien Dubuque, a native of Canada, obtained from the Sacs and Foxes a grant or lease of land for mining purposes. His claim included seven leagues on the west bank of the Mississippi, from the mouth of the Little Maquoketa to the Tete des Morts and three leagues deep. The area includes most of the productive crevices of Dubuque county. Lead is reported to have been discovered here seven years previously by the wife of Peosta. Dubuque at once took possession of his claim and began mining operations. The place became known as "Spanish Mines" or more commonly as Dubuque's Lead mines. In 1796 he petitioned Carondelet, the Spanish Governor of Louisiana, that the tract be granted him by patent from the Spanish government. His request was allowed and was subsequently confirmed by the board of land commissioners of Louisiana. Dubuque continued to develop his prospects until his death in $\mathbf{1 8 1 0 .}$

*Histoire le L' Academie Royale des Sciences. 1752. 
It was twenty years later however, before the mines of the State began to be actively developed. During 1830 several miners from Galena, influenced by the reports they had heard of the Dubuque region, crossed the river and obtaining the consent of the Indians commenced work where the city now stands. One of the first to be opened was the Langworthy crevice on Eagle Point avenue.

But the land on the west of the Mississippi, though it had come under the control of the United States by the Louisiana purchase still belonged to the Iudians, and the government, to keep the treaty with them soon ordered the miners to leave and subsequently sent troops from Prairie du Chien to enforce the order.

Two years later, at the close of the Black Hawk war, the large tract known as the Black Hawk purchase, including one-third of the present area of Iowa, was ceded to the United States by the Saes and Foxes. After the completion of the treaty negotiations the miners again crossed over into the much coveted region where they built cabins and commenced to take out considerable ore. But a second time they were forced to leave because the treaty had not been ratified. In June, 1833, the treaty went into effect, and the way was at length clear for settlers to take possession of the land. During the next few years large numbers flocked in, prospecting was actively carried on and many mines were soon in operation.

A superintendent of mines was appointed by the government and a system of permits to miners and smelters was adopted. For some years the smelters were required to pay six per cent. of all the lead produced. This tax was the cause of much dissatisfaction and was abolished at the end of ten years.

The first "legislation" in Iowa dates from 1830. In June of that year a number of miners met on the banks of the Mississippi and enacted regulations to govern them in their relations to each other. One of the articles was that "every man shall hold 200 yards square of ground by working said ground one day in six." The most productive period of the 


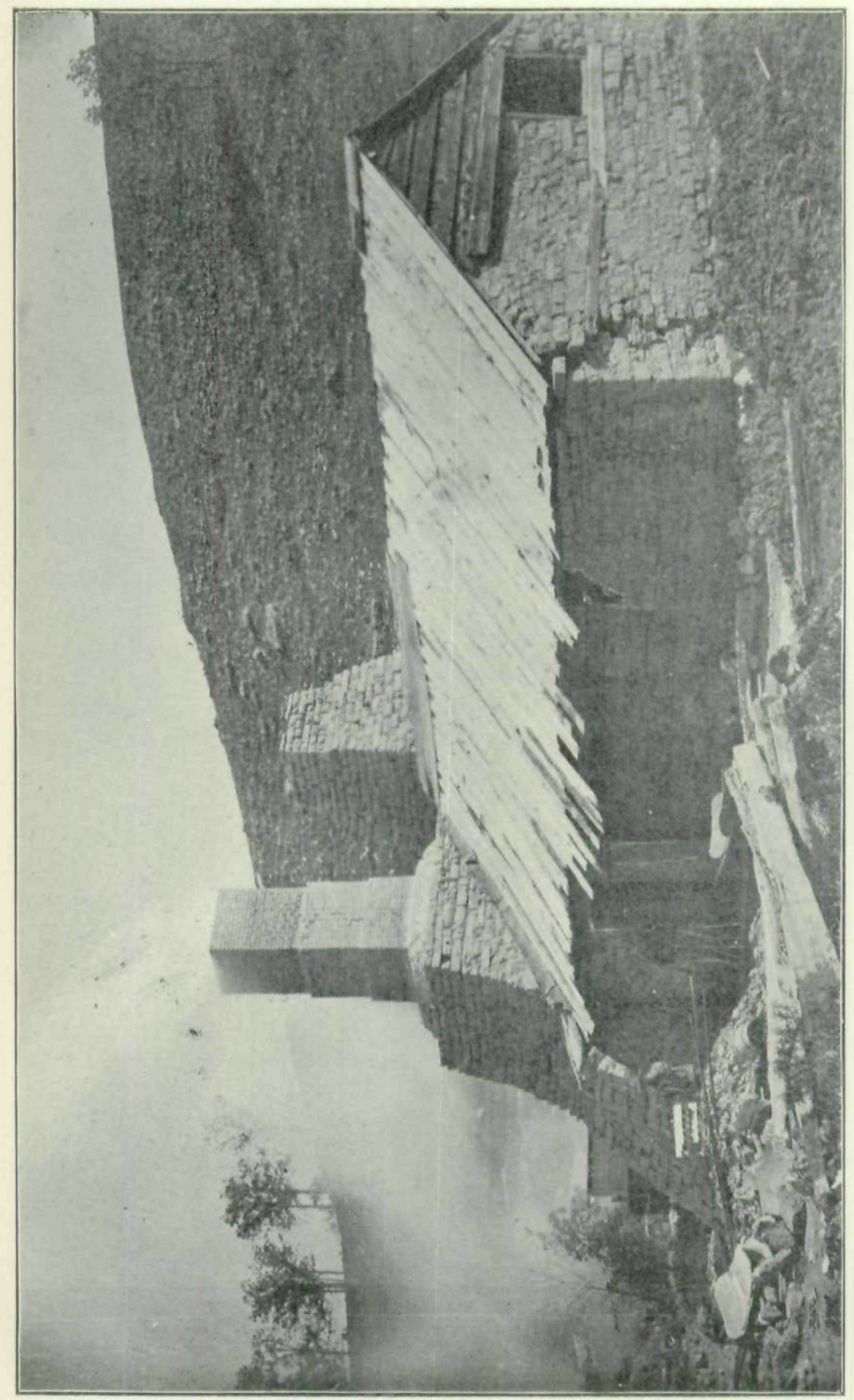

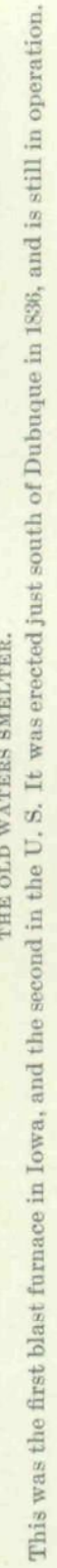


Dubuque mines was probably during the years 1835 to 1849 . No record was kept of the amount produced nor can this now be accurately ascertained. Owen* gives the output for 1839 as over $3,000,000$ pounds. In $18548,770,000$ pounds. of lead were exported from Dubuque.

Furnaces were early established for smelting purposes. The first contrivance employed was the primitive one of the Indians, though on a larger scale. A foundation or platform of rock was built about fifteen feet square, the cracks between the stones being carefully filled, and the platform made to slope towards the center. A layer of logs was placed on the rude hearth thus constructed, then a layer of ore and so alternately until there was enough for the blast. The wood was then fired and the pile allowed to burn down. The metal as it melted sought the lower part of the platform, where it was drawn off from time to time. This process was very wasteful, as besides consuming great quantities of timber it secured less than 50 per cent. of the lead. The rich slag thus left behind was eagerly sought in later years.

The next method of smelting employed was what is known as the cupola furnace, a great improvement over the former system, since by its use 65 to 70 per cent. of the lead was obtained. In 1834Peter Lorimier built one of these furnaces at the mouth of Caifish creek, this being the first of the kind in the State. The next year two others were constructed, one on the little Maquoketa and another in the city of $\mathrm{Du}$ buque. But it still remained true that quite a large per cent. of mineral was not extracted, and this loss brought about the adoption of the hearth furnace. The first one of these erected in America for smelting lead ore was built in Wisconsin in 1835, about midway between Dubuque and Mineral Point. The second in the country, and the first in Iowa, was located on Catfish ereek, just above Rock Dale in Dubuque county. This furnace, which has played an important part in the mining industry of the State, has been in operation more or less since its establishment, and it is still running. [See engraving.]

\footnotetext{
*Ex. Doc. 1st Sess. 26 Cong. Vol. VI, 39-40.
} 
With the hearth furnace practically all of the lead is extracted from the ore, and hence it is so much superior to the earlier processes employed that it soon replaced them. There were several of these furnaces in the vicinity of Dubuque. Besides the one already mentioned, may be named Mr. Brunskill's, on Catfish creek near Center Grove, and Nathan Simpson's, not far northeast of Dubuque.

It was not until 1860 that zine came into the market, and since then the production of this kindred metal has rapidly increased. During the ten years previous to 1882 the output of zinc more than doubled that of lead, while in 1889, according to the last federal census, the production was 13 to 1 for the entire region.

The principal ore of zinc now shipped from the Iowa mines is the carbonate, or "dry bone" of the miners. Until some thirteen years ago this material was regarded as worthless and was thrown away on the dump piles, or the workings were abandoned when it appeared.

In the fall of 1880 two wagon loads were taken to Benton, Wisconsin, and sold for $\$ 16$ a ton. So far as known, this was the first zinc ore marketed from the mines of the State, and from this time on the carbonate has been removed in rapidly increasing amounts. The first mine to be worked for zinc was the MeNulty (often called the Avenue Top) at the head of Julien avenue, Dubuque. This had previously been operated for lead, and $\$ 25,000$ worth is said to have been taken from it. The galena gave out in the crevices and a short distance beyond the zinc carbonate began to appear. It is estimated that this mine has yielded not less than $\$ 50$,000 worth of zinc. After the sale of the first "dry hone" many began at once to search for it, and numerous mines were soon being operated. Old lead diggings that had been abandoned when the associated metal began to appear, were again opened up and worked. 
Copyright of Annals of Iowa is the property of State of Iowa, by \& through the State Historical Society of Iowa and its content may not be copied or emailed to multiple sites or posted to a listserv without the copyright holder's express written permission. However, users may print, download, or email articles for individual use. 